УДК $630 * 232.13+630 * 181.351$

DOI: $10.37482 / 0536-1036-2020-5-119-130$

\title{
EVALUATION OF ECOLOGICAL PLASTICITY AND STABILITY OF SOME PROMISING VARIETIES OF POPLARS
}

\author{
A.P. Tsarev ${ }^{1}$, Doctor of Agriculture, Prof.; ResearcherID: S-6639-2019, \\ ORCID: https://orcid.org/0000-0001-8019-0016 \\ V.A. Tsarev ${ }^{1}$, Candidate of Agriculture, Assoc. Prof.; \\ ORCID: https://orcid.org/0000-0002-3921-9339 \\ R.P. Tsareva ${ }^{1}$, Candidate of Agriculture, Senior Research Scientist; \\ ORCID: https://orcid.org/0000-0002-6949-4665 \\ N.V. Laur ${ }^{2}$, Doctor of Agriculture, Assoc. Prof.; \\ ORCID: https://orcid.org/0000-0003-1989-0384 \\ ${ }^{1}$ All-Russian Research Institute of Forest Genetics, Breeding and Biotechnology, \\ ul. Lomonosova, 105, Voronezh, 394087, Russian Federation; \\ e-mail: antsa-55@yandex.ru,vad.tsareff@yandex.ru,tsarais42@mail.ru \\ ${ }^{2}$ Petrozavodsk State University, prosp. Lenina, 33, Petrozavodsk, 185910, Russian Federation; \\ e-mail: laur@petrsu.ru
}

When developing promising assortments of forest woody plants, it is important to take into account not only their growth and survival in some particular environment, but also their respond to change in growing conditions. In this regard, the purpose of this work is to evaluate the ecological plasticity and stability of some poplar varieties promising for the southeastern part of European Russia and Ukraine using the Eberhart and Russell method. The research was carried out on three testing sites: upland environment of the forest-steppe zone of the Voronezh region; floodplain environment of the dry steppe zone of the Volgograd region; and floodplain environment of the steppe zone of the Donetsk region. Five promising poplar varieties were identified and studied at each of the experimental sites. The indices of survival, growth in height and diameter, trunk volumes, and productivity by wood stocks and average increments are presented for each variety. Due to the average increments change with age, the ontogeny period from 21 to 30 years was chosen for the study, during which the average survival of poplars varies slightly. It was found that Regenerata, which is characterized by average plasticity and the lowest stability, was the most productive of the studied poplar varieties. It can perform high productivity only in the favorable environment. The poplar variety Pioneer demonstrated the least plasticity. Its productivity did not vary too much with change in growth conditions at average ecological stability. The highest plasticity at average ecological stability was observed in the Vernirubens variety. Average plasticity and stability were observed in poplar E.s.-38. The poplar variety Marilandica was also characterized by average plasticity, and high ecological stability. The research results allow using of the studied varieties more rational in different growing conditions, with regard to their environmental characteristics.

For citation: Tsarev A.P., Tsarev V.A., Tsareva R.P., Laur N.V. Evaluation of Ecological Plasticity and Stability of Some Promising Varieties of Poplars. Lesnoy Zhurnal [Russian Forestry Journal], 2020, no. 5, pp. 119-130. DOI: 10.37482/0536-1036-2020-5-119-130

Keywords: poplar varieties, survival, growth, productivity, ecological plasticity, ecological stability, Eberhart and Russell method.

\section{Introduction}

Most species of the genus Populus L. are fast-growing woody plants. In lowforest regions of the world, poplars are the most promising species of woody plants that can quickly fill the existing shortage of wood. That was the reason for their wide reproduction and breeding in many countries of the world. 
Some experiments on poplar breeding were conducted in different countries, but the first extensive practical work on hybridization of poplars for the purposes of the pulp and paper industry was carried out by American researchers A. Stout, R. McKee, and E. Schreiner. In these studies, 13 thousand hybrid seedlings were obtained; 69 promising forms were selected for further testing [42].

An extensive summary report on poplar culture and breeding in the Netherlands, Germany and other Western European countries was presented by G. Houtzagers [35, 36] and H. Günther [31]. At the same time, H. Günther gave not only a general description of some isolated forms of poplars, in particular euramerican hybrids of black poplars, but also hypothesized their origin.

Taking into account the great economic importance of poplars, the Food and Agriculture Organization of the United Nations (FAO) created in 1947 the International Poplar Commission (IPC) with the tasks of comprehensive research of this species, development of promising varieties, technologies for its cultivation and use. This is the only tree species for which such a division of the FAO has been established. Currently, IPC includes 38 countries, either heavily- or low-forested, but countries with advanced economies (USA, Canada, Germany, England, France, Italy, Spain, Japan, China, India, Turkey, etc.). Unfortunately, Russia is not one of them.

Over the years of its existence, IPC has published three large summarizing reports on the systematics, breeding, environmental sustainability and culture of poplars in different countries of the world, as well as on their rational use [39, 40, 41]. In addition to these reports on poplar, works on various problems were published in different countries. It is impossible to list all of them, but some that investigate the issues of breeding and hybridization are worth mentioning. These are foreign publications [27, 30, 34, 45], as well as works of Russian researchers with aspen $[6,7]$, white $[4,10]$, black pyramidal $[1,15,26]$, balsamic $[2,3,7]$ and other poplars $[19,21,22]$.

In the former USSR, starting from the 1950's-60's, in various site conditions, test poplar cultures were laid out. After many years of testing, promising recommended assortments were selected and even developed for different positions. So, in the Leningrad region such work was carried out by P.L. Bogdanov [3], in the Moscow region - A.S. Yablokov [26], in the Central forest-steppe and steppe - M.M. Veresin, S.P. Ivannikov, S.A. Rostovtsev and A.P. Tsarev [4, 6, 13, 20], in the Volgograd region - A.V. Albensky, R.P. Tsareva and V.A. Tsarev $[1,25]$ in the Urals N.A. Konovalov [7], in Uzbekistan - G.P. Ozolin [10], in Kazakhstan P.P. Besschetnov [2], in Ukraine - N.V. Starova, A.P. Tsarev et al. [15, 23]. For various purposes, such work was carried out in other regions too [13, 21, 22, 24].

However, once developed an excellent assortment requires constant updating, due to several factors, the main of which listed below.

As civilization develops, the requirements for wood raw materials change from time to time. Such as for instance, in recent decades, more and more woody biomass is required for the development of bioenergy of renewable resources. In other words, varieties and technologies that can give the maximum volume of initial production within the shortest possible time come to the fore [33, 34]. Approaches to landscape gardening are changing. Some places require alley planting, solitary trees or pyramidal forms, and others require spreading and weeping forms, etc.

It is necessary to consider that during ontogenesis certain failures of varieties show through due to the appearance of new or introduced quarantine diseases and 
pests to which local varieties are not adapted. This happened with the most heavyproductive variety of poplar in Italy I-214. Due to its high quality it became widely used in various countries of Western Europe (its share in the total poplar cultivation reached $30 \%$ and more). But suddenly there was an outbreak of a disease caused by the pathogen Marssonina brunnea [38], which became a disaster for this poplar. It was necessary to urgently develop work on breeding new varieties resistant to this disease.

The varieties bred, tested and shown excellent results in one region do not always fulfill the expectations in other regions. Thus, in the Central Chernozem Region the magnificent Italian varieties of black poplars could not withstand winter frosts, and winter-hardy poplar hybrids bred by P.L. Bogdanov in Leningrad were not drought-resistant $[19,24]$.

In accordance with the world practice, especially after the disaster of the 1960's in Western Europe, associated with the disease Marssonina brunnea, technologies for creating poplar plantations from a set of many different varieties with similar practical properties, but with different genotypic structure were adopted. In particular, O. Lange [37] recommended creating plantings not from a single variety, but from 30-50 clonal varieties that are homogeneous in growth strength, ecological stability and morphological similarity, but distinguished by genotypic composition.

Considering the above mentioned, when cultivating poplars, like other woody and non-woody plants, it is necessary to take into account not only their productivity, but also ecological plasticity and stability. This is precisely what is missed in many cases due to the need for long-term, and often, multi-regional research. Research in this direction has relevance and novelty.

There are a number of methods for evaluation of ecological stability and plasticity of plant varieties which were developed by G. Wricke [44], S. Eberhart and W. Russell [29], G. Tai and D. Young [43], M.A. Fedin and D.Ya. Silis [18], V.G. Potanin et al. [12]. The analysis of some of these methods conducted by Novosibirsk researchers V.G. Potanin, A.F. Aleynikov and P.I. Styopochkin showed that each of them has advantages and disadvantages [12].

In our country, the method of Eberhart and Russell was often used. It was considered in detail by V.Z. Pakudin [11] and used by different researchers for evaluating the ecological stability and plasticity of different plants in different regions $[8,9,16]$. However, for poplars it was only used in the Astrakhan semi-desert [19]. Therefore, in this paper, we have tried for the first time to extend the application of this method.

The purpose of our work was to evaluate the ecological plasticity and stability of some promising poplar varieties for the South-Eastern part of European Russia and Ukraine using the Eberhart and Russell method and to determine their suitability for practical use in various cultivation conditions.

\section{Research objects and methods}

To evaluate the ecological plasticity and stability, three variety testing sites were selected. One of them located in the upland conditions of the Voronezh region and the others in the floodplain conditions of the Volgograd and Donetsk regions. On these sites, for evaluation of the level of ecological stability, five of the same promising varieties were selected. Among them there are three euramerican hybrids 
of black poplars: Vernirubens (Populus $\times$ euramericana (Dode) Guinier cv. 'Vernirubens'), Marilandica (Populus $\times$ euramericana (Dode) Guinier cv. 'Marilandica') and Regenerata-79 (Populus $\times$ euramericana (Dode) Guinier cv. 'Regenerata'); as well as two domestic hybrids: Pioneer (Populus pyramidalis L. $\times$ Populus nigra L.) bred by A.S. Yablokov [26] and E.s.-38 (Populus deltoides Marsh. $\times$ Populus balsamifera L.) bred by M.M. Veresin, who named it as Voronezhsky Giant $[4,26]$.

In the Voronezh region research was carried out on the Semiluky populetum laid out in 1974 by A.P. Tsarev in accordance with the methods of field testing [5, 28]. Preplanting preparation of soil was in the fall plowing to a depth of $30 \mathrm{~cm}$. Planting was carried out with stem cuttings of different varieties and clones of poplars; 84 representatives of different sections of poplars were introduced to the site [19].

The site area was 4.6 ha, the size was $296 \times 155 \mathrm{~m}$. The soil is leached chernozem (black soil). The terrain is a weak water-dividing slope to the Veduga river. The groundwater level was 4-5 $\mathrm{m}$. The forest site type is $D_{2}$, according to the integrated scheme of P.S. Pogrebnyak and P.P. Kozhevnikov, which means that the soil is fertile (grey forest and chernozem) and slightly moist. Plant spacing was $5 \times 4 \mathrm{~m}$. The experiment was carried out in 4 replications. Plot allocation in replications was randomized. There were 6 ramets (one clone plants) on the plot. So, each clone or variety was represented by 24 plants on an area of $480 \mathrm{~m}^{2}$. Materials of field observations of 25 -year old trees were used for this site.

In the Volgograd region, the study object was pilot-production crop testing site laid out in 1988 by R.P. Tsareva together with employees of the Podtelkovsky forestry in the floodplain of the Kumylga River. The soil is intrazonal floodplain chernozem-meadow layered-grained heavy loam. The area of the plot is 2.0 ha. Planting is carried out by 1 -year old rooted seedlings with plant spacing of $4 \times 4 \mathrm{~m}$. Each variety is represented by at least two replications. Eighteen different clones and varieties of poplar were planted on the site, 30-70 copies of each. The studied varieties were represented as follows: Vernirubens, 49 copies; Marilandica, 31 copies; Pioneer, 44 copies; Regenerata, 38 copies; and E.s.-38, 70 copies [25]. Materials of field observations of 29-year old trees were used for this site.

In the Donetsk region research was carried out on the variety testing site laid out in 1977 by A.P. Tsarev together with employees of the Fedorovsky forest district of the Zhdanov (now Mariupol) forestry pertaining to the Donetsk Forestry Management Department in Urochishche Ksenevka (no. 50), located in the floodplain of the Karatysh River. The forest site type is $E_{2-3}$, according to the integrated scheme of P.S. Pogrebnyak and P.P. Kozhevnikov, which means that the soil is low-fertile (degraded chernozem and transitional to them slightly alkalinized loams), slightly moist and moist. The occurrence of ground water varied from optimal $(1.0-1.5 \mathrm{~m})$ to complete swamping. Comparative studies were carried out on the part of the site with optimal groundwater occurrence. The total area of the site was 1.2 ha, including the accounting area of 0.61 ha $(135 \times 45 \mathrm{~m})$. Plant spacing is $3 \times 3 \mathrm{~m}$. The total number of plants was 1,215 pcs, including 675 accounting plants. The planting pattern was the method of complete random blocks. Plot allocation on the site and the mixing of plants on the plot were randomized. There were 3 replications. Planting was carried out with stem cuttings $20 \mathrm{~cm}$ long. The number of plants in the plot was 25 pcs. Into the test 9 clones and varieties of poplars were introduced [23]. Materials of field observations of 21-year old trees were used for this site. 
Plant survival, growth dynamics in height (at an early age using a measuring pole, and then - using the German Blume Leiss altimeter) and diameter at breast height $(1.3 \mathrm{~m})$ were established by complete enumeration of trees. Trunk volumes were determined by volume tables for poplar [32].

Wood stock was determined by summing up the actual volumes of survived trees of each variety or clone on each plot for each replication and converting the resulting stock value to the area of 1 ha using the equation (1):

$$
W=\frac{W^{\prime} \cdot 10,000}{S_{p}}
$$

where $W$ - calculated wood stock, $\mathrm{m}^{3} / \mathrm{ha} ; W^{\prime}-$ actual wood stock on the plots, obtained as the sum of stocks on each plot, $\mathrm{m}^{3} ; S_{p}$ - total area of all plots of each variety, $\mathrm{m}^{2} ; 10,000$ - area of a hectare, $\mathrm{m}^{2}$.

Standard valuation and mathematical methods as well as Microsoft Excel program were used for data processing $[5,14,17]$.

The average increments in stocks of stem wood were determined based on these indicators. Since the stands were of different ages, the average increments in wood stocks were used to evaluate the ecological stability. According to our data [24], the average increments of poplars in the period of ontogenesis from 20 to 30 years vary slightly, so their use in this study is quite acceptable.

The method of Eberhart and Russell, according to which the ecological plasticity and stability of the studied varieties were evaluated, uses two main parameters:

- Coefficient of productivity regression for changes in environmental conditions, which allows characterizing of varieties by their plasticity;

- The standard deviation of actual productivity indices from the regression line, which characterizes the stability of productivity in different environmental conditions.

In general, this method is expressed by the following dependency (equation 2):

$$
X_{i j}=\bar{X}_{i}+r_{i} I_{j}+d_{i j}
$$

where $X_{i j}$ - productivity of the $i$-th variety in the $j$-th testing site; $i=1,2,3, \ldots, V ; j$ $=1,2,3, \ldots, n ; \bar{X}_{i}$ - average productivity of the $i$-th variety for all testing sites; $r_{i}-$ the regression coefficient of the $i$-th variety on changing of wood stock productivity (see equation 4); $I_{j}$ - index of environmental conditions for the $j$-th testing site (see equation 3); $d_{i j}$ - deviation from the regression line of the $i$-th variety in the $j$-th testing site.

Additional details of the method are presented in the discussion of research results.

\section{Research results and discussion}

The average indices of survival, height and diameter of the studied varieties in different environmental conditions are shown in table 1. 
Survival and growth of poplars in different environmental conditions

\begin{tabular}{|c|c|c|c|c|}
\hline \multirow[b]{2}{*}{$\begin{array}{c}\text { Poplar } \\
\text { varieties }\end{array}$} & \multirow[b]{2}{*}{ Survival and growth indices } & \multicolumn{3}{|c|}{ Testing sites } \\
\hline & & $\begin{array}{c}\text { Semiluky } \\
\text { populetum, } \\
\text { Voronezh region }\end{array}$ & $\begin{array}{l}\text { Kumylga, } \\
\text { Volgograd region }\end{array}$ & $\begin{array}{l}\text { Ksenevka, } \\
\text { Donetsk } \\
\text { region }\end{array}$ \\
\hline \multirow{3}{*}{ Vernirubens } & Survival, \% & 88 & 79 & 92 \\
\hline & Height, m & $31.7 \pm 0.83$ & $24.7 \pm 0.74$ & $27.0 \pm 0.32$ \\
\hline & Diameter, cm & $38.1 \pm 1.71$ & $28.8 \pm 1.97$ & $31.7 \pm 0.92$ \\
\hline \multirow{3}{*}{ Marilandica } & Survival, \% & 88 & 77 & 86 \\
\hline & Height, m & $28.7 \pm 0.43$ & $24.0 \pm 0.45$ & $26.2 \pm 0.44$ \\
\hline & Diameter, cm & $40.4 \pm 1.25$ & $27.5 \pm 1.17$ & $30.6 \pm 1.14$ \\
\hline \multirow{3}{*}{ Regenerata-79 } & Survival, \% & 71 & 89 & 85 \\
\hline & Height, m & $33.6 \pm 0.64$ & $24.2 \pm 0.46$ & $27.3 \pm 0.37$ \\
\hline & Diameter, cm & $48.0 \pm 1.24$ & $27.7 \pm 1.12$ & $32.0 \pm 1.03$ \\
\hline \multirow{3}{*}{ Pioneer } & Survival, \% & 50 & 70 & 74 \\
\hline & Height, m & $33.6 \pm 0.78$ & $24.8 \pm 0.63$ & $23.1 \pm 0.37$ \\
\hline & Diameter, cm & $40.5 \pm 1.99$ & $30.6 \pm 1.65$ & $27.8 \pm 0.77$ \\
\hline \multirow{3}{*}{ E.s.-38 } & Survival, \% & 100 & 88 & 98 \\
\hline & Height, m & $28.5 \pm 0.25$ & $24.5 \pm 0.36$ & $25.5 \pm 0.24$ \\
\hline & Diameter, cm & $36.6 \pm 1.05$ & $28.1 \pm 1.04$ & $29.6 \pm 0.48$ \\
\hline
\end{tabular}

Data on average trunk volumes, wood stocks and stock increments were calculated (table 2), according to the indices shown in table 1. To evaluate the ecological stability of the average increment using equation 2 , its components were found.

Thus, the calculated average value of actual average increments of poplars in the interval of ontogeny from 20 to 30 years $\left(\bar{X}_{L}\right)$ for the Vernirubens variety was $28.3 \mathrm{~m}^{3} /$ ha/year, for Marilandica it was $25.6 \mathrm{~m}^{3} /$ ha/year, for Pioneer $19.2 \mathrm{~m}^{3} / \mathrm{ha} /$ year, for Regenerata $-32.8 \mathrm{~m}^{3} /$ ha/year and for E.s. $-38-26.0 \mathrm{~m}^{3} /$ ha/year.

Table 2

Productivity indices of poplars in different environmental conditions

\begin{tabular}{|c|c|c|c|c|}
\hline \multirow[b]{2}{*}{$\begin{array}{c}\text { Poplar } \\
\text { varieties }\end{array}$} & \multirow[b]{2}{*}{ Productivity indices } & \multicolumn{3}{|c|}{ Testing sites } \\
\hline & & $\begin{array}{l}\text { Semiluky } \\
\text { populetum, } \\
\text { Voronezh } \\
\text { region }\end{array}$ & $\begin{array}{l}\text { Kumylga, } \\
\text { Volgograd } \\
\text { region }\end{array}$ & $\begin{array}{l}\text { Ksenevka, } \\
\text { Donetsk } \\
\text { region }\end{array}$ \\
\hline \multirow{3}{*}{ Vernirubens } & Trunk volume, $\mathrm{m}^{3}$ & 1.39 & 0.62 & 0.83 \\
\hline & Wood stock, $\mathrm{m}^{3} / \mathrm{ha}$ & 612 & 612 & 840 \\
\hline & Average increment, $\mathrm{m}^{3} / \mathrm{ha} / \mathrm{yr}$ & 24.5 & 20.4 & 40.0 \\
\hline \multirow{3}{*}{ Marilandica } & Trunk volume, $\mathrm{m}^{3}$ & 1.42 & 0.56 & 0.75 \\
\hline & Wood stock, $\mathrm{m}^{3} / \mathrm{ha}$ & 624 & 539 & 711 \\
\hline & Average increment, $\mathrm{m}^{3} / \mathrm{ha} / \mathrm{yr}$ & 25.0 & 18.0 & 33.8 \\
\hline \multirow{3}{*}{ Regenerata-79 } & Trunk volume, $\mathrm{m}^{3}$ & 2.22 & 0.59 & 0.86 \\
\hline & Wood stock, $\mathrm{m}^{3} / \mathrm{ha}$ & 976 & 634 & 804 \\
\hline & Average increment, $\mathrm{m}^{3} / \mathrm{ha} / \mathrm{yr}$ & 39.0 & 21.1 & 38.3 \\
\hline \multirow{3}{*}{ Pioneer } & Trunk volume, $\mathrm{m}^{3}$ & 1.64 & 0.65 & 0.55 \\
\hline & Wood stock, $\mathrm{m}^{3} / \mathrm{ha}$ & 410 & 604 & 445 \\
\hline & Average increment, $\mathrm{m}^{3} / \mathrm{ha} / \mathrm{yr}$ & 16.4 & 20.1 & 21.2 \\
\hline \multirow{3}{*}{ E.s.-38 } & Trunk volume, $\mathrm{m}^{3}$ & 1.14 & 0.69 & 0.68 \\
\hline & Wood stock, $\mathrm{m}^{3} / \mathrm{ha}$ & 569 & 604 & 737 \\
\hline & Average increment, $\mathrm{m}^{3} / \mathrm{ha} / \mathrm{yr}$ & 22.8 & 20.1 & 35.1 \\
\hline
\end{tabular}

The index of environmental conditions for the $j$-th testing site $\left(I_{j}\right)$ is calculated using equation 3 : 


$$
I_{j}=\frac{\sum_{\mathrm{i}} \mathrm{X}_{i j}}{V}-\frac{\sum_{i} \sum_{j} \mathrm{X}_{i j}}{V \cdot n}
$$

where $V$-number of testing varieties, $V=5 ; n$-number of testing sites, $n=3$.

Calculations have shown that for the Semiluky populetum testing site $I_{1}=$ $=-0.9$; for the Kumylga testing site $I_{2}=-6.4$ and for the Ksenevka testing site $I_{3}=$ $=+7.3$.

Based on the fact that the higher index of environmental conditions, the more favorable environmental conditions for the testing varieties, the most favorable for poplars were the Ksenevka environmental conditions in the Donetsk region. The average environmental conditions can be attributed to Semiluky populetum and the least favorable for growth of poplars were the environmental conditions of the Kumylga testing site, located in the dry-steppe zone of the European Russia.

The regression coefficient of the $i$-th variety for the change in the average increment $r_{i}$ was calculated using equation 4 :

$$
\mathrm{r}_{\mathrm{i}}=\frac{\sum_{j} \mathrm{X}_{i j} I_{j}}{\sum_{j} I_{j}^{2}}
$$

The calculations have shown that for the Vernirubens variety $r_{1}=1.466$, for Marilandica $r_{2}=1.147$, for Regenerata $r_{3}=1.148$, for Pioneer $r_{4}=0.106$ and for E.s.-38 $r_{5}=1.126$.

According to the hypothesis of S. Eberhart and W. Russell, the higher regression coefficient, the greater response of the variety to change in environmental conditions. In other words, it has higher plasticity and responds positively on improving of environmental conditions. And vice versa, the lower regression coefficient, the lower plasticity of the variety and it less changes its productivity depending on change in environmental conditions. In our case, the ranking has shown that the highest rank (1) was in the Vernirubens variety, it had the highest plasticity. The average ranks were for the varieties Regenerata, Marilandica and E.s.-38 (2-4, respectively), and the lowest (5) - for the Pioneer variety. That is, in this case, the Pioneer variety, whose growth was less than other poplars (most likely this is due to its lower rooting and survival), has shown the lowest plasticity. Thus, its productivity, depending on improvement or degradation of environmental conditions in comparison with other poplars, changed less.

Hereafter, the theoretical average increments $\left(\widehat{X_{i j}}\right)$ were calculated using equation 5:

$$
\widehat{X_{i j}}=\overline{X_{i}}+r_{i} I_{j}
$$

They are presented in the table 3 .

Table 3

Theoretical average increments of poplars in different environmental conditions

$\left(\mathrm{m}^{3} / \mathrm{ha} /\right.$ year $)$

\begin{tabular}{|c|c|c|c|c|c|}
\hline \multirow{2}{*}{$\begin{array}{c}\text { Poplar } \\
\text { varieties }\end{array}$} & $\begin{array}{c}\text { Semiluky } \\
\text { populetum, } \\
\text { Voronezh region }\end{array}$ & $\begin{array}{c}\text { Kumylga, } \\
\text { Volgograd } \\
\text { region }\end{array}$ & $\begin{array}{c}\text { Ksenevka, } \\
\text { Donetsk } \\
\text { region }\end{array}$ & Sum & $\begin{array}{c}\text { Average } \\
\text { increment }\end{array}$ \\
\hline Vernirubens & 27.0 & 18.9 & 39.0 & 84.9 & 28.3 \\
\hline Marilandica & 24.6 & 18.3 & 33.9 & 76.8 & 25.6 \\
\hline Regenerata-79 & 31.8 & 25.4 & 41.2 & 98.5 & 32.8 \\
\hline Pioneer & 19.1 & 18.6 & 20.0 & 57.7 & 19.2 \\
\hline E.s.-38 & 25.0 & 18.8 & 34.2 & 78.0 & 26.0 \\
\hline
\end{tabular}


As can be seen from the table 3 data and the actual average increments of the studied poplar varieties in table 2, the average values of the theoretical and actual increments on all testing sites are the same. However, these values may be different for each specific testing site. The deviations of the theoretical and actual values of the poplars' average increments obtained in this experiment are presented in table 4 .

Table 4

Deviations of the theoretical and actual values of average increments of poplars

\begin{tabular}{|c|c|c|c|c|}
\hline \multirow{2}{*}{$\begin{array}{c}\text { Poplar } \\
\text { varieties }\end{array}$} & $\begin{array}{c}\text { Semiluky } \\
\text { populetum, } \\
\text { Voronezh region }\end{array}$ & $\begin{array}{c}\text { Kumylga, } \\
\text { Volgograd } \\
\text { region }\end{array}$ & $\begin{array}{c}\text { Ksenevka, } \\
\text { Donetsk } \\
\text { region }\end{array}$ & $\begin{array}{c}\text { Sum } \\
\text { of squared } \\
\text { deviations }\end{array}$ \\
\hline Vernirubens & -2.5 & +1.5 & +1.0 & 9.50 \\
\hline Marilandica & +0.4 & -0.3 & -0.2 & 0.26 \\
\hline Regenerata-79 & +7.2 & -4.3 & -2.9 & 78.74 \\
\hline Pioneer & -2.7 & +1.6 & +1.2 & 10.98 \\
\hline E.s.-38 & -2.2 & +1.3 & +0.9 & 7.34 \\
\hline
\end{tabular}

In the general case, to get the value of ecological stability variance for each variety, the sum of squared deviations of the theoretical from the actual values is divided by the number of degrees of freedom (equation 6):

$$
S_{i}^{2}=\frac{\sum_{j} d_{i j}^{2}}{n-2},
$$

where $S_{i}^{2}$ - variance of ecological stability for each variety.

In our case, since the number of testing sites is 3 , the stability variance is equal to the sum of squared deviations given in table. 4 .

As can be seen from the table 4 data, the Marilandica variety is distinguished by the highest stability of the average trunk wood increments in all of the studied testing sites. The average stability of the average trunk wood increments can be attributed to the following poplar varieties: E.s.-38, Vernirubens and Pioneer. The most productive poplar variety Regenerata in all environmental conditions of the studied testing sites showed the lowest variance of ecological stability.

\section{Conclusion}

The conducted research of a group of promising poplars on three testing sites of the forest-steppe and steppe zone of our country allowed to establish not only their phenotypic characteristics on survival, growth and productivity, but also their ecological plasticity and stability.

It was found that the most productive of the studied varieties was Regenerata. It was characterized by the average plasticity, but the lowest stability. So, it can perform high productivity only in the favorable environment for growth.

Poplar Pioneer, despite the fact that it was inferior in productivity to other varieties, was the most plastic with average ecological stability. Its productivity did not change too much with change in environmental conditions.

The Vernirubens variety has shown the minimum ecological plasticity with medium ecological stability.

Average indices of plasticity and stability are noted in the poplar variety E.s.-38, which allows it to be used in various environmental conditions.

Poplar Marilandica has demonstrated average plasticity and high stability. 
In general, the studies have shown that poplar variety testing in different environment conditions allows obtaining a more complete characteristic of them, taking into account ecological plasticity and stability. This makes it possible to determine more appropriate ways for their using in afforestation and other applications in forest management.

\section{REFERENCES}

1. Альбенский А.В. Селекция древесных пород и семеноводство. М.; Л.: Гослесбумиздат, 1959. 306 с. [Al'benskiy A.V. Tree Breeding and Seed Production. Moscow, Goslesbumizdat Publ., 1959. 306 p.].

2. Бессчетнов П.П. Тополь (культура и селекция). Алма-Ата: Изд-во Наука, 1981. 152 c. [Besschetnov P.P. Poplar (Planting and Breeding). Alma-Ata, Nauka Publ., 1981. 152 p.].

3. Богданов П.Л. Тополя и их культура. М.: Лесн. пром-сть, 1965. 104 с. [Bogdanov P.L. Poplars and Their Planting. Moscow, Lesnaya promyshlennost' Publ., 1965. 104 p.].

4. Вересин M.M. Новый гибридный тополь для лесных культур и озеленения // Лесохоз. информ., 1974. № 6. С. 14-15. [Veresin M.M. A New Hybrid Poplar for Forest Plantations and Landscaping. Lesokhozyaystvennaya informatsiya [Forestry information], 1974, no. 6, pp. 14-15].

5. Доспехов Б.А. Методика полевого опыта (с основами статистической обработки результатов исследований). 3-е изд. перер. и доп. М.: Колос, 1973. 336 с. [Dospekhov B.A. Methods of Field Test (with the Basics of Statistical Processing of Research Results). Moscow, Kolos Publ., 1973. 336 p.].

6. Иванников С.П. Тополь. М.: Лесн. пром-сть. 1980. 85 с. [Ivannikov S.P. Poplar. Moscow, Lesnaya promyshlennost' Publ., 1980. 85 p.].

7. Коновалов Н.А. Селекция быстрорастущих древесных пород на Среднем Урале // Лесн. хоз-во, 1963. № 7. С. 55-58. [Konovalov N.A. Breeding of Fast-Growing Tree Species in the Middle Urals. Lesnoye khozyaystvo, 1963, no. 7, pp. 55-58].

8. Краснова Ю.С., Шаманин В.П., Петуховский С.Л., Кирилюк Л.М. Экологическая пластичность сортов мягкой яровой пшеницы в условиях южной лесостепи Западной Сибири // Современные проблемы науки и образования. 2014. № 6. Режим доступа: http://science-education.ru/ru/article/view?id=16182 (дата обращения: 10.01.20). [Krasnova Yu.S., Shamanin V.P., Petukhovskiy S.L., Kirilyuk L.M. Ecological Plasticity of Grades of the Soft Springwheat in the Conditions of the Southern Forest-Steppe of Western Siberia. Sovremennyye problemy nauki i obrazovaniya [Modern problems of science and education], 2014, no. 6].

9. Наквасина Е.Н., Демина Н.А. Экологическая стабильность географических рас ели обыкновенной // Вестн. Сев. (Арктич.) федер. ун-та. Сер.: Естеств. науки. 2014, № 2. C. 61-70. [Nakvasina E.N., Demina N.A. Ecological Stability of Geographical Races of Spruce. Vestnik Severnogo (Arkticheskogo) federal'nogo universiteta. Seriya: Estestvennyye nauki [Vestnik of Northern (Arctic) Federal University. Series "Natural Sciences"], 2014, no. 2, pp. 61-70].

10. Озолин Г.П. Селекция тополя в Узбекистане. Ташкент: РИО МСХ УзССР, 1962. 198 c. [Ozolin G.P. Poplar Breeding in Uzbekistan. Tashkent, RIO MSKh Uzbek SSR Publ., 1962. 198 p.].

11. Пакудин В.3. Оценка экологической пластичности сортов // Генетический анализ количественных и качественных признаков с помощью математикостатистических методов / науч. ред.: М.А. Федин, В.А. Драгавцев. М.: ВНИИТЭИсельхо3, 1973. С. 40-44. [Pakudin V.Z. Estimation of Ecological Plasticity of Varieties. Genetic Analysis of Quantitative and Qualitative Characteristics Using Mathematical and Statistical Methods. Moscow, VNIITEIsel'khoz Publ., 1973, pp. 40-44]. 
12. Потанин В.Г., Алейников А.Ф., Степочкин П.И. Новый подход к оценке экологической пластичности сортов растений // Вавилов. журн. генетики и селекции. 2014. T. 18, № 3. C. 548-552. [Potanin V.G., Aleinikov A.F., Stepochkin P.I. A New Approach to Estimation of the Ecological Plasticity of Plant Varieties. Vavilovskij zurnal genetiki $i$ selekcii [Vavilov Journal of Genetics and Breeding], 2014, vol. 18, no. 3, pp. 548-552].

13. Ростовцев C.A. Районирование культуры сортовых тополей в европейской части РСФСР. М.: ВДНХ СССР, 1963. 6 с. [Rostovtsev S.A. Zoning of Poplar Culture in the European Part of the USSR. Moscow, VDNKh SSSR Publ., 1963. 6 p.].

14. Снедекор Дж.У. Статистические методы в применении к исследованиям в сельском хозяйстве и биологии. М.: Сельхозиздат, 1961. 503 с. [Snedecor G.W. Statistical Methods Applied to Experiments in Agriculture and Biology. Moscow, Sel'khozizdat Publ., 1961. 503 p.].

15. Старова Н.В. Селекция ивовых. М.: Лесн. пром-сть, 1980. 208 с. [Starova N.V. Breeding of Salicaceae Family. Moscow, Lesnaya promyshlennost' Publ., 1980. 208 p.].

16. Ториков B.E., Богомаз O.A. Экологическая пластичность новых сортов картофеля // Вестн. Брян. гос. с.-х. акад. 2008. № 4. С. 60-63. [Torikov V.E., Bogomaz O.A. Ecological Plasticity and Stability by New Kinds of Potato. Vestnik Bryanskoy gosudarstvennoy sel'skokhozyaystvennoy akademii, 2008, no. 4, pp. 60-63].

17. Тюрин А.В. Таксация леса. 2-е изд. М.: Гослестехиздат, 1945. 376 с. [Tyurin A.V. Forest Inventory. Moscow, Goslestekhizdat Publ., 1945. 376 p.].

18. Федин М.А., Силис Д.Я. Определение взаимодействия генотип-среда // Генетический анализ количественных и качественных признаков с помощью математико-статистических методов / науч. ред.: М.А. Федин, В.А. Драгавцев. М.: ВНИИТЭИсельхо3, 1973. С. 58-62. [Fedin M.A., Silis D.Ya. Determining the Interaction GenotypeEnvironment. Genetic Analysis of Quantitative and Qualitative Characteristics Using Mathematical and Statistical Methods. Ed. by M.A. Fedin, V.A. Dragavtsev. Moscow, VNIITEIsel'khoz Publ., 1973, pp. 58-62].

19. Царев А.П. Сортоведение тополя. Воронеж: Изд-во ВГУ, 1985. 152 с. [Tsarev A.P. Research of Poplar Varieties. Voronezh, VGU Publ., 1985. 152 p.].

20. Царев А.П. Рекомендации по выращиванию насаждений тополя в юговосточной части европейской территории РСФСР. Воронеж: Изд-во ЦНИИЛГиС (ВНПО «Союзлесселекция»), 1986. 37 c. [Tsarev A.P. Recommendations for Growing Poplar Plantations in the South-Eastern Part of the European Territory of the RSFSR. Voronezh, TsNIILGiS Publ., 1986. 37 p.].

21. Царев А.П. Программы лесной селекции в России и за рубежом: моногр. М.: МГУЛ, 2013. 164 с. [Tsarev A.P. Programs of Forest Tree Breeding in Russia and Abroad: Monograph. Moscow, MGUL Publ., 2013. 164 p.].

22. Царев А.П., Погиба С.П., Лаур Н.В. Селекция лесных и декоративных древесных растений / под общ. ред. А.П. Царева. М.: МГУЛ, 2014. 552 с. [Tsarev A.P., Pogiba S.P., Laur N.V. Breeding of Forest and Decorative Woody Plants. Ed. by A.P. Tsarev. Moscow, MGUL Publ., 2014. 552 p.].

23. Царев А.П., Царева Р.П., Сапах А.Н. Отбор форм тополя для степной зоны европейской части СССР // Селекция ценных форм древесных пород и их использование для создания целевых насаждений. Воронеж: ЦНИИЛГиС, 1989. С. 71-78. [Tsarev A.P., Tsareva R.P., Sapakh A.N. Selection of Poplar Forms for the Steppe Zone of the European Part of the USSR. Selection of Valuable Forms of Tree Species and Their Use for Creating Target Plantations. Voronezh, TsNIILGiS Publ., 1989, pp. 71-78].

24. Царев А.П., Царева Р.П., Царев В.А. Динамика сохранности и продуктивности настоящих тополей при испытании в условиях умеренного климата // Информ. вестн. ВОГиС. Т. 14, № 2. 2010. С. 255-264. [Tsarev A.P., Tsareva R.P., Tsarev V.A. The Time Pattern of Survival and Productivity of Eupopulus Tested in the Temperate Climatic Belt. Informatsionnyy vestnik VOGiS [VOGiS Herald], 2010, vol. 14, no. 2, pp. 255-264].

25. Царева Р.П., Царев В.А. Результаты многолетних испытаний различных форм и гибридов тополей в Волгоградской области // Тр. Кубан. гос. аграр. ун-та. 
2018. Вып. 4(73). C. 244-248. [Tsareva R.P., Tsarev V.A. The Long-Term Testing Results of Various Poplars' Forms and Hybrids in Volgograd Region. Trudy Kubanskogo gosudarstvennogo agrarnogo universiteta [Proceedings of the Kuban State Agrarian University], 2018, iss. 73, pp. 244-248]. DOI: 10.21515/1999-1703-73-244-248

26. Яблоков А.С. Пирамидальные тополи. М.: Л.: Гослесбумиздат, 1956. 58 с. [Yablokov A.S. Pyramidal Poplars. Moscow, Goslesbumizdat Publ., 1956. 58 p.].

27. Carle J. Trends and Perspectives in Poplar and Willow Cultivation - A Global Synthesis of National Progress. Abstracts of Submitted Papers and Posters of the International Poplar Commission: Poplars and Other Fast-Growing Trees - Renewable Resources for Future Green Economies. Rome, FAO, 2016, p. 1.

28. Cochran W.G., Cox G.M. Experimental Designs. New York, John Wiley \& Sons, 1957. $618 \mathrm{p}$.

29. Eberhart S.A., Russel W.A. Stability Parameters for Comparing Varieties. Crop Science, 1966, vol. 6, iss. 1, pp. 36-40. DOI: 10.2135/cropsci1966.0011183X000600010011x

30. First International Conference on the Future of Poplar Culture. Rome, November 13-15, 2003. Rome, FAO Headquarters - Reports and Round Tables, 2003. 114 p.

31. Günther H. Leitfaden für den Pappelanbau. Berlin, Deutscher Bauernverlag, 1956. $199 \mathrm{~S}$.

32. Hadži-Georgiev K. Goguŝevski M. Dvolazne tabele mass za topola klona Populus euramericana cv. I-214 u gevgeliskom području. Topola, 1972, T. XVI, no. 90, pp. 25-29.

33. Hofmann M. Pappeln als nachwach-sender Rohstoff auf Ackerstandorten - Kulturverfahren, Ökologie und Wachstum unter dem Aspekt der Sortenwahl. Dissertation. Münden, Universität Göttingen, Schriften des Forschungsinstitutes für schnellwachsende Baumarten Hann, 2005, Bd. 8, 145 S.

34. Hofmann M., Janßen A. Genetic Improvement of Poplar and Prospects for Poplar Cultivation in Germany. Abstracts of Submitted Papers and Posters of the International Poplar Commission: Poplars and Other Fast-Growing Trees - Renewable Resources for Future Green Economies. Rome, FAO, 2016, p. 39.

35. Houtzagers G. Het Geslacht Populus Verband met zijn Beteekenis voor de Houtteelt [The Genus Populus and Its Significance in Silviculture]. Vageningen, H. Veenman \& Zonen, 1937. $266 \mathrm{~S}$.

36. Houtzagers G. Die Gattung Populus und ihre forstliche Bedeutung. Hannover, Verlag M. \& H. Schaper, 1941. 196 S.

37. Lange O. Zum Stand der Pappelforshung in Westdeuthland. Allgemeine Forstund Jagdzeitung, 1976, Bd. 31, S. 430-431.

38. Ostry M., Ramstedt M., Newcombe G., Steenackers M. Diseases of Poplars and Willows. Poplars and Willows - Trees for Society and the Environment. Ed. by J.G. Isebrands, J. Richardson. Rome, FAO, 2014, pp. 443-458.

39. Poplars and Willows in Wood Production and Land Use. Rome, FAO, 1979. 328 p.

40. Poplars and Willows - Trees for Society and the Environment. Ed. by J.S. Isebrands, J. Richardson. Rome, FAO, 2014. 634 p.

41. Poplars in Forestry and Land Use. Rome, FAO, 1958. 511 p.

42. Stout A.B., Schreiner E.J. Results of a Project in Hybridizing Poplars. Journal of Heredity, 1933, vol. 24, iss. 6, pp. 217-229. DOI: 10.1093/oxfordjournals.jhered.a103780

43. Tai G.C.C., Young D.A. Genotypic Stability Analysis of Eight Potato Varieties Tested in Series of Ten Trials. American Potato Journal, 1972, vol. 49, iss. 4, pp. 138-150. DOI: $\underline{10.1007 / \mathrm{BF} 02861594}$

44. Wricke G. Die Erfassung der Wechselwirkung zwischen Genotyp und Umwelt bei quantitative Eigenschaften. Zeitsschrift für Pflanzenzüchtung, 1965, Bd. 53, S. 267-343.

45. Zsuffa L., Giordano E., Pryor L.D., Stettler R.F. Trends in Poplar Culture: Some Global and Regional Perspectives. Biology of Populus and its Implications for Management and Conservation. Ed. by R.F. Stettler, Jr. H.D. Bradshaw, P.E. Heilman, T.M. Yinckley. Ottawa, NRC Research Press, 1996, pp. 515-539. 


\section{ОЦЕНКА ЭКОЛОГИЧЕСКОЙ ПЛАСТИЧНОСТИ И СТАБИЛЬНОСТИ НЕКОТОРЫХ ПЕРСПЕКТИВНЫХ СОРТОВ ТОПОЛЕЙ}

A.П. Царев ${ }^{1}$, д-р с.-х. наук, проф.; ResearcherID: S-6639-2019, ORCID: https://orcid.org/0000-0001-8019-0016

В.А. Царев ${ }^{1}$, канд. с.-х. наук, доu.; ORCID: https://orcid.org/0000-0002-3921-9339

P.П. Царева ${ }^{1}$, канд. с.-х. наук, ст. науч. сотр.;

ORCID: https://orcid.org/0000-0002-6949-4665

H.B. Лаур ${ }^{2}$, д-p c.-х. наук, доu.; ORCID: https://orcid.org/0000-0003-1989-0384

${ }^{1}$ Всероссийский научно-исследовательский институт лесной генетики, селекции и биотехнологии, ул. Ломоносова, д. 105, г. Воронеж, Россия, 394087; e-mail: antsa-55@yandex.ru, vad.tsareff@yandex.ru, tsarais42@mail.ru

${ }^{2}$ Петрозаводский государственный университет, просп. Ленина, д. 33, г. Петрозаводск, Республика Карелия, Россия, 185910; e-mail: laur@petrsu.ru

При разработке перспективных ассортиментов лесных древесных растений важно учитывать не только их рост и сохранность в каких-то одних условиях местопроизрастания, но и реакцию на изменение условий местопроизрастания. Цель исследования - анализ экологической пластичности и стабильности некоторых перспективных сортов тополей для юго-восточной части европейской территории России и Украины методом С. Эберхарта и В. Рассела. Исследования проводились в нагорных условиях лесостепной зоны Воронежской области и в пойменных условиях степной зоны Волгоградской и Донецкой областей. На каждом из экспериментальных объектов выделено и изучено по 5 перспективных сортов тополей. По каждому сорту приведены показатели его сохранности, роста в высоту и диаметра, объема стволов и продуктивности по запасам и средним приростам. Ввиду того, что средние приросты меняются с возрастом, выбран отрезок онтогенеза с 21 года до 30 лет, в течение которого средний прирост тополей изменяется незначительно. Установлено, что самым продуктивным из исследованных сортов является тополь сорта «Регенерата», отличающийся средней пластичностью, но самой низкой стабильностью. Он показывает высокую продуктивность только в благоприятных для роста условиях. Тополь «Пионер» наименее пластичен. Его продуктивность не очень сильно варьирует с изменением условий роста при средней экологической стабильности. Наибольшая пластичность при средней экологической стабильности была отмечена у сорта «Вернирубенс». Средние показатели пластичности и стабильности наблюдались у тополя сорта «Эс-38». Тополь «Мариландика» также отличается средней пластичностью, но высокой экологической стабильностью. Полученные результаты исследований позволяют более рационально использовать изученные сорта в различных условиях местопроизрастания с учетом их экологических характеристик.

Для цитирования: Tsarev A.P., Tsarev V.A., Tsareva R.P., Laur N.V. Evaluation of Ecological Plasticity and Stability of Some Promising Varieties of Poplars // Изв. вузов. Лесн. журн. 2020. № 5. С. 119-130. DOI: 10.37482/0536-1036-2020-5-119-130

Ключевые слова: сорта тополей, сохранность, рост, продуктивность, экологическая пластичность, экологическая стабильность, метод Эберхарта и Рассела.

Поступила 17.02.20 / Received on February 17, 2020 